\title{
ИНФЕКЦИОННЫЕ БОЛЕЗНИ INFECTIOUS DISEASES
}

DOI: 10.29413/ABS.2020-5.5.3

\section{Изучение гуморального иммунного ответа при лёгкой и бессимптомной формах проявления COVID-19}

Балахонов С.В. ' , Дубровина В.И. ', Чеснокова М.В. ', Войткова В.В. ', Пятидесятникова А.Б. ',

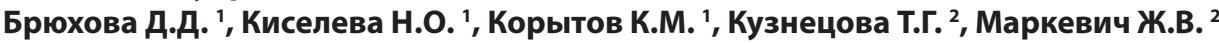

\begin{abstract}
1 ФКУЗ Иркутский научно-исследовательский противочумный институт Сибири и Дальнего Востока Федеральной службы по надзору в сфере защиты прав потребителей и благополучия человека (664047, г. Иркутск, ул. Трилиссера, 78, Россия);

${ }^{2}$ ОГБУ3 «Районная больница г. Бодайбо» (666904, Иркутская область, г. Бодайбо, ул. 30 лет Победы, 6, Россия)
\end{abstract}

Автор, ответственный за переписку: Дубровина Валентина Ивановна, e-mail: dubrovina-valya@mail.ru

\begin{abstract}
Резюме
Актуальность. В настоящее время в условиях пандемии COVID-19 одной из наиболее актуальных задач здравоохранения является обеспечение безопасности населения Российской Федерации. Сведений о длительности и напряжённости постинфекционного иммунитета в отношении SARS-CoV-2 coбрано недостаточно, особенно при инаппарантных (без клинических признаков), лёгких или стёртых формах проявления инфекции.

Материалы и методы. В исследовании приняли участие 99 добровольцев с лабораторно подтверждённым методом ПЦР диагнозом COVID-19 - прибывшие на работу в г. Бодайбо вахтовым методом жители Иркутской области и других регионов Российской Федерации, а также 50 условно здоровых лиц, проживающих в г. Иркутске и имеющих на момент обследования отрищательные результаты ПцР на наличие PHK SARS-CoV-2.

Специфические антитела IgG и IgM к SARS-CoV-2 определяли в сыворотке крови методом иммуноферментного анализа (ИФА) с использованием тест-систем «ИФА анти-SARS-CoV-2 IgG» (ФБУН ГНЦ ПМБ, 2. Оболенск), «SARS-CoV-2-IgG-ИФА-БЕСТ» и «SARS-CoV-2-IgM-ИФА-БЕСТ» (AО «Вектор-Бест», г. Новосибирск). Результаты. Представлены результаты исследования гуморального иммунитета пациентов с бессимптомной и манифестной формами проявления COVID-19. Полученные данные свидетельствуют о выработке специфических Ig в в сыворотке крови людей на 2-3-й неделях после инфицирования вирусом SARS-Cov-2 и достижении их максимального уровня на 20-21-й день болезни. Показатель сероконверсии составил 94,9\%. Показано, что среднегеометрический титр антител при бессимптомной и лёгкой формах проявления коронавирусной инфекции статистически не различался и составлял 1:512 и 1:632 соответственно. Более высокие титры антител (1:1600) выявляли при среднетяжелой форме.

Заключение. Результаты исследований могут послужить основой для изучения динамики изменений показателей гуморального иммунного ответа у переболевших COVID-19 и выяснения длительности их постинфекционного иммунитета с целью прогнозирования развития эпидемической ситуации и обеспечения планирования специфической профилактики.
\end{abstract}

Ключевые слова: гуморальный иммунитет, специфические антитела, COVID-19, SARS-CoV-2

Для цитирования: Балахонов С.В., Дубровина В.И., Чеснокова М.В., Войткова В.В., Пятидесятникова А.Б., Брюхова Д.Д., Киселева Н.О., Корытов К.М., Кузнецова Т.Г., Маркевич Ж.В. Изучение гуморального иммунного ответа при лёгкой и бессимптомной формах проявления COVID-19. Acta biomedica scientifica. 2020; 5(5): 26-30. doi: 10.29413/ABS.2020-5.5.3

\section{Studying Humoral Immune Response at Mild and Asymptomatic COVID-19 Forms}

\author{
Balakhonov S.V. ${ }^{1}$, Dubrovina V.I. ${ }^{1}$, Chesnokova M.V. ${ }^{1}$, Voitkova V.V. ${ }^{1}$, Pyatidesyatnikova A.B. ${ }^{\text {, }}$ \\ Bryukhova D.D. ${ }^{1}$, Kiseleva N.O. ${ }^{1}$, Korytov K.M. ${ }^{1}$, Kuznetsova T.G. ${ }^{2}$, Markevich Zh.V. ${ }^{2}$ \\ ${ }^{1}$ Irkutsk Antiplague Research Institute of Siberia and Far East of Rospotrebnadzor (Trilissera str. 78, Irkutsk 664047, Russian \\ Federation); ${ }^{2}$ Bodaybo District Hospital (30 let Pobedy str. 6, Bodaybo 666904, Irkutsk Region, Russian Federation)
}

Corresponding author: Valentina I. Dubrovina, e-mail: dubrovina-valya@mail.ru

\begin{abstract}
Background. Currently, during the COVID-19 pandemic, one of the most pressing healthcare problems is to ensure the safety of the population of the Russian Federation. There is insufficient information on the duration and intensity of post-infectious immunity in relation to SARS-CoV-2, especially in case of inapparent (without clinical signs), mild or latent forms of infection.

Materials and methods. The study involved 99 volunteers with a laboratory confirmed PCR diagnosis of COVID-19 who were residents of the Irkutsk Region and of other regions of the Russian Federation and arrived to work in Bodaybo
\end{abstract}


on a rotational basis. Also the study included 50 conditionally healthy people living in Irkutsk who had negative PCR results for SARS-CoV-2 RNA presence.

Specific IgG and IgM antibodies to SARS-CoV-2 were detected in blood serum by enzyme-linked immunosorbent assay (ELISA) using test systems "ELISA anti-SARS-CoV-2 IgG" (FBUN SSC PMB, Obolensk, Russian Federation), "SARS-CoV2-IgG-IFA-BEST" and "SARS-CoV-2-IgM-IFA-BEST" (Vector-Best, Novosibirsk, Russian Federation).

Results. The results of a study of the humoral immunity of patients with asymptomatic and clinical forms of COVID-19 are presented. The data indicate the production of specific IgG in the blood serum of people in 2-3 weeks after SARSCov-2 infection and reaching its maximum level on the 20-21 st day. The seroconversion rate was $94.9 \%$. It was shown that the geometric mean titer of antibodies in asymptomatic and mild forms of coronavirus infection did not differ statistically and amounted to 1:512 and 1:632, respectively. Higher titers of antibodies (1:1600) were detected in the moderate form.

Conclusion. The research results can serve as a basis for studying the dynamics of changes in the indicators of the humoral immune response in patients with COVID-19 and for clarifying the duration of their post-infectious immunity in order to predict the development of the epidemic situation and to ensure the planning of specific prevention.

Key words: humoral immunity, specific antibodies, COVID-19, SARS-CoV-2

For citation: Balakhonov S.V., Dubrovina V.I., Chesnokova M.V., Voitkova V.V., Pyatidesyatnikova A.B., Bryukhova D.D., Kiseleva N.O., Korytov K.M., Kuznetsova T.G., Markevich Zh.V. Studying Humoral Immune Response at Mild and Asymptomatic COVID-19 Forms. Acta biomedica scientifica. 2020; 5(5): 26-30. doi: 10.29413/ABS.2020-5.5.3

Эпидемическая вспышка новой коронавирусной инфекции COVID-19, вызванная вирусом SARS-CoV-2, впервые зарегистрированная в г.Ухань провинции Хубей (КНР) в декабре 2019 г., имела высокую скорость пандемического распространение более чем в 200 странах мира $[1,2,3]$. Этому способствовали аэрозольный механизм передачи возбудителя инфекции от человека к человеку, длительный инкубационный период до 14 дней, высокая миграционная активность населения [4]. В мире на 06.08.2020 г. зарегистрировано 189959939 случаев COVID-19 (показатель заболеваемости - 2417,2 на 100 тыс. населения), умерли 711560 человек (летальность 3,7 \%). В 85 субъектах Российской Федерации выявлено 871894 заболевших новой коронавирусной инфекцией (594,2 на 100 тыс. населения), умерли 14606 человек (летальность 1,7\%) [5, 6].

Клинические варианты и проявления COVID-19 варьируют от ОРЗ, трахеита, бронхита до внебольничных пневмоний, острого дистресс-синдрома, повреждения почек, миокарда, ЦНС, которые могут привести к смерти пациентов. По оперативным данным управлений Роспотребнадзора 10 субъектов Сибирского и Дальневосточного федеральных округов, из зарегистрированных 59266 случаев COVID-19 в 67,7 \% наблюдений (40 152 случая) заболевание протекает бессимптомно (42,0 \%) или в лёгкой форме (25,8 \%).

Известно, что иммунный ответ при COVID-19 формируется преимущественно по клеточному типу. Продукция цитокинов, генерируемая антигенпрезентирующими клетками, обусловливает общую адаптивную реакцию, а активация цитотоксических Т-клеток приводит к элиминации вируса из организма $[7,8,9]$. Гуморальный иммунный ответ, обусловленный продукцией специфических антител разных классов (lgM, lgG), а также вирус нейтрализующих антител (Nab) ответственны за защиту организма от повторного заражения $[10,11]$. Однако сведений о длительности и напряжённости постинфекционного иммунитета в отношении SARS-CoV-2 недостаточно, особенно при инаппаратных (без клинических признаков), лёгких или стёртых формах проявления инфекции.

\section{ЦЕЛЬ РАБОТЫ}

Оценка динамики формирования постинфекционного иммунного ответа среди вахтовых рабочих, переболевших лёгкой или бессимптомной формами COVID-19 в период эпидемического осложнения на одном из золотодобывающих предприятий Иркутской области.

\section{МАТЕРИАЛ И МЕТОДЫ ИССЛЕДОВАНИЯ}

На основании оперативной информации управления Роспотребнадзора по Иркутской области проведена оценка эпидемиологической ситуации по коронавирусной инфекции в г. Бодайбо Бодайбинского района Иркутской области.

Для изучения постинфекционного иммунитета методом случайной выборки были сформированы две группы обследуемых в возрасте от 18 до 69 лет. Первая группа («опытная») включала 99 человек, прибывших на работу вахтовым методом в г. Бодайбо, из которых 23,2 \% (23 чел.) - жители Иркутской области и 76,8 \% (76 чел.) - жители других регионов Российской Федерации. Все они имели контакт с больным COVID-19 в период самоизоляции, госпитализированы в районную больницу на основании обнаружения PHK SARS-CoV-2 методом полимеразной цепной реакции (ПЦР). Во вторую группу («контрольная») включены 50 условно здоровых лиц, проживающих в г. Иркутске и имеющих на момент обследования отрицательные результаты ПЦР на наличие PHK SARS-CoV-2.

Для тестирования проб на наличие специфических IgG к SARS-CoV-2 использовали набор реагентов для анализа сыворотки или плазмы крови человека «ИФА анти-SARS-CoV-2 IgG» (серия 4, с. г. 12.2020, производитель ФБУН ГНЦ ПМБ, г. Оболенск) и набор реагентов для ИФА «SARS-CoV-2-lgG-ИФА-БЕСТ» (серия 7, с. г. 26.05.2021, производитель АО «Вектор-Бест», г. Новосибирск). Наличие специфических IgM к SARS-CoV-2 определяли с помощью набора реагентов «SARS-CoV-2-IgM-ИФА-БЕСТ» (серия 6, с.г. 26.05.2021, производитель АО «Вектор-Бест», г. Новосибирск). Исследования проведены с 9.06.2020 г. пох15.06.2020 г. Объём составил 596 исследований. Учёт оптической плотности осуществляли на автоматическом ридере ELx $808 \mathrm{IU}$ (Biotek Instruments Inc., США).

Для оценки формирования постинфекционного иммунитета проведены расчёты по трём показателям: доля серонегативных лиц, доля серопозитивных лиц и среднегеометрический титр (СГТ) антител. СГТ определяли по формуле $\lg _{\mathrm{x}}=\sum \log _{2} a_{i} n_{i} / \sum n_{i}$. Статистическую обработку материала проводили с помощью программы Statistica 6.0 (StatSoft Inc., США). 


\section{ЭТИЧЕСКАЯ ЭКСПЕРТИЗА}

В работе с добровольцами соблюдались этические принципы, предъявляемые Хельсинкской декларацией Всемирной медицинской ассоциации. Все участники прошли предварительное анкетирование и подписали письменное информированное согласие на участие в исследовании. Протокол утверждён локальным этическим комитетом ФКУЗ Иркутский научно-исследовательский противочумный институт Роспотребнадзора.

\section{РЕЗУЛЬТАТЫ И ОБСУЖДЕНИЕ}

Первые два случая коронавирусной инфекции зарегистрированы 2.05.2020 г. у двух местных жителей г. Бодайбо, прибывших из Москвы. Следующий случай выявлен 3.05.2020 г. у мужчины 44 лет, который прибыл в г. Бодайбо на работу вахтовым методом в ПАО «Высочайший» из г. Красноярска 19.04.2020 г. 20.04.2020 г. он был обследован в коммерческой лаборатории г. СанктПетербурга на COVID-2019 с отрицательным результатом, находился на самоизоляции, клиника заболевания появилась 21.04.2020 г. 30.04.2020 г. с признаками пневмонии мужчина госпитализирован в реанимацию, 2.05.2020 г. получен положительный результат ПЦР в ФКУЗ Иркутский научно-исследовательский противочумный институт Роспотребнадзора. 4.05.2020 г. пациент умер. В последующем среди местных жителей и вахтовых рабочих золотодобывающих предприятий г. Бодайбо в результате лабораторного обследования было выявлено 245 случаев COVID-19, в том числе 223 (91,0\%) выявленных инфицированных/заболевших были среди вахтовых рабочих, находившихся в самоизоляции в период «перевахтовки» с 6.05.2020 г. по 6.06.2020 г. (рис. 1).

В период с 19.05.2020 г. по 29.05.2020 г. в Бодайбинскую районную больницу с подтверждённым ПЦР диагнозом COVID-19 госпитализированы 99 вахтовых рабочих. Заболевания протекали преимущественно в бессимптомной $(n=47 ; 47,5 \%)$ и лёгкой $(n=49 ; 49,5 \%)$ формах, у 3 пациентов (3,0 \%) - в средней степени тяжести. Отмечено, что заболевание COVID-19 характеризо- валось слабостью и повышением температуры от субфебрильной до $38,6^{\circ} \mathrm{C}(100,0 \%)$, нарушением обоняния в течение 3-4 дней (92,2 \%), першением в горле (37,3\%), сухим кашлем (3,9 \%), затруднённым дыханием (1,9\%).

Результаты серологического обследования на наличие специфических антител к коронавирусу в ИФА представлены в таблице 1 .

При изучении антительного иммунного ответа в контрольной группе обследованных лиц специфические IgG к SARS-CoV-2 не выявлены.

При исследовании сывороток крови пациентов с диагнозом COVID-19 (опытная группа) доля серопозитивных составила 94,9\% при 95\% доверительном интервале (ДИ) (92,7-97,1\%), у 5 пациентов антительный ответ не наблюдался (5,1 \%; 95\% ДИ 2,9-7,3 \%), что связано с показателями IgG к SARS-CoV-2 ниже диагностических титров на момент исследований.

При этом одновременное выявление IgM и IgG к коронавирусу SARS-CoV-2 обнаружено в 35,1 \% случаев ( $n=33 ; 95 \%$ ДИ 30,2-40,0\%), только $\lg$ - в 64,9\% ( $n=61 ; 95 \%$ ДИ 59,9-69,8 \%), только IgМ не обнаружены ни в одном случае.

Установлено, что на 8-14-е сутки от начала болезни специфические IgG к SARS-CoV-2 выявлялись у 49,0\% обследованныхлиц; наличие как IgM, так и lgG к коронавирусув этот же период зарегистрировано у 46,7 \% пациентов; к 15-28-му дню эти показатели составили 72,2 \% и 22,2 \% соответственно. При этом пик специфических $\lg M+\operatorname{lgG}$ выявлен на 10-11-й день болезни, IgG - на 20-21-й день болезни. Полученные результаты свидетельствуют о подтверждении диагноза COVID-19 и нахождении обследуемых либо в период разгара заболевания при одновременном выявлении специфических IgM и lgG, либо в период реконвалесценции, когда уровень IgG повышается, а уровень IgМ снижается.

Минимальный показатель серопозитивности по $\lg \mathrm{G}$ (1:100) выявлен у 3 пациентов (3,2\%), максимальный (1:3200) - у 1 заболевшего. У превалирующего числа больных (74,5 \%) титр антител составил 1:800-1:1600

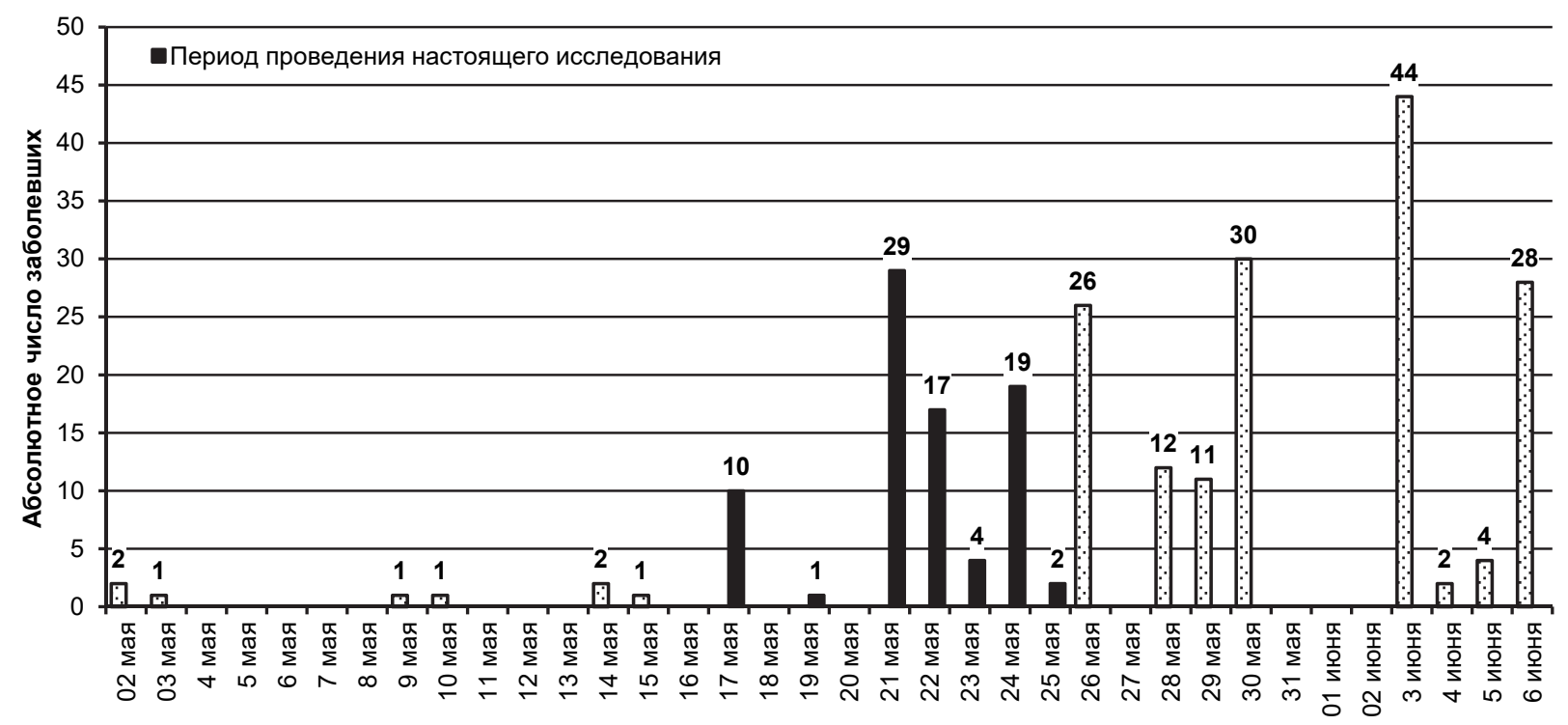

Дни регистрации заболевания

Рис. 1. Динамика заболеваемости COVID-19 среди местных жителей и вахтовых рабочих г. Бодайбо с 6.05 .2020 г. по 6.06.2020 г. (абс.). Fig. 1. Dynamics of the incidence of COVID-19 among local residents and shift workers in Bodaybo from 05/06/2020 to 06/06/2020 (absolute numbers). 
Результаты серологического обследования на наличие специфических IgG к SARS-CoV-2 больных COVID-19 в Бодайбинском районе Иркутской области (май 2020 г.)

Table 1 The results of serologic examination for specific IgG to SARS-CoV-2 in patients with COVID-19 in Bodaybo district of the Irkutsk region (May 2020)

\begin{tabular}{|c|c|c|c|c|c|c|c|c|c|c|c|}
\hline \multirow{2}{*}{\multicolumn{2}{|c|}{ Степень тяжести }} & \multirow{2}{*}{ Кол-во } & \multicolumn{2}{|c|}{ ИФА } & \multicolumn{6}{|c|}{$\begin{array}{c}\text { Количество положительных результатов ИФА } \\
\text { в титрах }\end{array}$} & \multirow{2}{*}{ Сгт } \\
\hline & & & Отрицательный & Положительный & $1: 100$ & $1: 200$ & $1: 400$ & $1: 800$ & $1: 1600$ & $1: 3200$ & \\
\hline \multicolumn{2}{|c|}{ Бессимптомное } & 47 & 1 & 46 & 1 & 1 & 10 & 14 & 17 & 1 & $1: 512$ \\
\hline \multicolumn{2}{|l|}{ Лёгкое } & 49 & 4 & 45 & 2 & 6 & 3 & 11 & 25 & 0 & $1: 632$ \\
\hline \multicolumn{2}{|c|}{ Средней тяжести } & 3 & 0 & 3 & 0 & 0 & 0 & 0 & 3 & 0 & $1: 1600$ \\
\hline \multirow{2}{*}{ итого } & абс. & 99 & 5 & 94 & 3 & 7 & 13 & 25 & 45 & 1 & \multirow{2}{*}{$1: 835$} \\
\hline & $\%$ & 100 & 5,1 & 94,9 & 3,2 & 7,4 & 13,8 & 26,6 & 47,9 & 1,1 & \\
\hline
\end{tabular}

при среднегеометрическом титре 1:835. При этом показатель СГТ к вирусу SARS-Cov-2 при бессимптомной форме проявления инфекции определён как 1:512, при лёгкой 1:632, при средне-тяжёлой - 1:1600 (табл. 1).

Таким образом, проведённые исследования по оценке гуморального иммунитета у пациентов с бессимптомной и манифестной формами проявления COVID-19 подтверждают выработку специфических IgG на 2-3-й неделях после инфицирования вирусом SARS-Cov-2 и достижение их максимального уровня на 20-21-й день болезни. Показатель сероконверсии составил 94,9 \%. Среднегеометрический титр антител при бессимптомной и лёгкой формах проявления коронавирусной инфекции статистически значимо не различается и равен 1:512 и 1:632 соответственно. Более высокие титры антител (1:1600) выявлены при среднетяжёлой форме.

В дальнейшем планируется изучение динамики изменения показателей иммунного ответа у переболевших COVID-19 и выяснение длительности их постинфекционного иммунитета с целью прогнозирования развития эпидемической ситуации и обеспечения планирования специфической профилактики.

\section{Конфликт интересов}

Авторы данной статьи сообщают об отсутствии конфликта интересов.

\section{ЛИТЕРАТУРА}

1. Кутырев В.В., Попова А.Ю., Смоленский И.Ю., Ежлова Е.Б., Демина Ю.В., Сафронов В.А., и др. Эпидемиологические особенности новой коронавирусной инфекции (Covid-19). Сообщение 1: Модели реализации профилактических и противоэпидемических мероприятий. Проблемы особо опасных инфекций. 2020; (1): 6-13. doi: 10.21055/0370-1069-2020-1-6-13

2. Кутырев В.В., Попова А.Ю., Смоленский И.Ю., Ежлова Е.Б., Демина Ю.В., Сафронов В.А., и др. Эпидемиологические особенности новой коронавирусной инфекции (COVID-19). Сообщение 2: Особенности течения эпидемического процесса COVID-19 во взаимосвязи с проводимыми противоэпидемическими мероприятиями в мире и Российской Федерации. Проблемы особо опасных инфекций. 2020; (2): 6-12. doi: 10.21055/0370-1069-2020-2-6-12

3. Львов Д.К., Альховский С.В., Колбухина Л.В., Бурцева Е.И. Этиология эпидемической вспышки Covid-19 в г. Ухань (провинция Хубэй, Китайская Народная Республика), ассоциированной с вирусом 2019-nCov (Nidovirales, Coranaviridae, Coronavirinae, Betacoronavirus, подрод Sarbecovirus): уроки эпидемии SARS-CoV. Вопросы вирусологии. 2020; 65(1): 6-15. doi: 10.36233/0507-4088-2020-65-1-6-15
4. Брико Н.И., Каграманян И.Н., Никифоров В.В., Суранова Т.Г., Чернявская О.П., Полежаева Н.А. Пандемия Covid-19. Меры борьбы с ее распространением в Российской Федерации. Эпидемиология и вакцинопрофилактика. 2020; 19(2): 3-12. doi: 10.31631/2073-3046-2020-20-2-4-12

5. Worldometer. Пандемия коронавируса COVID-19. URL: https://www.worldometers.info/coronavirus/\#countries (дата обращения: 18.08.2020).

6. Официальная информация о коронавирусе в России. Onеративные данные. URL: https://стопкоронавирус.рф (дата обращения: 18.08.2020).

7. Бугоркова С.А. Некоторые аспекты формирования иммунного ответа у пациентов с COVID-19. COVID-19 Preprints [Preprint]. 2020. URL: https://covid19-preprints.microbe.ru/ article/21. doi: 10.21055/preprints-3111717

8. Garcia LF. Immune response, inflammation, and the clinical spectrum of COVID-19. Front Immunol. 2020; 11: 1441. doi: 10.3389/ fimmu.2020.01441

9. Maggi E, Canonica GW, Moretta L. Covid-19: Unanswered questions on immune response and pathogenesis. J Allergy Clin Immunol. 2020; 146(1): 18-22. doi: 10.1016/j.jaci.2020.05.001

10. Hou H, Wang T, Zhang B, Luo Y, Mao L, Wang F, et al. Detection of IgM and IgG antibodies in patients with coronavirus disease 2019. Clin Transl Immunology. 2020; 9(5): e01136. doi: 10.1002/cti2.1136

11. Liu J, Guo J, Xu Q, Cai G, Chen D, Shen Y. Detection of IgG antibody during the follow-up in patients with COVID-19 infection. Crit Care. 2020; 24(1): 448. doi: 10.1186/s13054-020-03138-4

\section{REFERENCES}

1. Kutyrev VV, Popova AYu, Smolensky VYu, Ezhlova EB, Demina YuV, Safronov VA, et al. Epidemiological features of new coronavirus infection (COVID-19). Communication 1: Modes of implementation of preventive and anti-epidemic measures. Problems of Particularly Dangerous Infections. 2020; (1): 6-13. doi: 10.21055/0370-1069-2020-1-6-13. (In Russ.)

2. Kutyrev VV, Popova AYu, Smolensky VYu, Ezhlova EB, Demina YuV, Safronov VA, et al. Epidemiological peculiarities of new coronavirus infection (COVID-2019). Communication 2: Peculiarities of epidemic process development in conjunction with performed anti-epidemic measures around the world and in the Russian Federation. Problems of Particularly Dangerous Infections. 2020; (2): 6-12. doi: 10.21055/0370-1069-2020-2-6-12. (In Russ.)

3. Lvov DK, Alkhovsky SV, Kolbukhina LV, Burtseva EI. Etiology of epidemic outbreaks COVID-19 in Wuhan, Hubei province, Chinese People Republic associated with 2019-nCoV (Nidovirales, Coronaviridae, Coronavirinae, Betacoronavirus, Subgenus Sarbecovirus): lessons of SARS-CoV outbreak. Problems of Virology. 2020; 65(1): 6-15. doi: 10.36233/0507-40882020-65-1-6-15. (In Russ.)

4. Briko NI, Kagramanyan IN, Nikiforov VV, Suranova TG Chernyavskaya OP, Polezhaeva NA. COVID-19 pandemic. Preven- 
tion measures in the Russian Federation. Epidemiology and Vaccinal Prevention. 2020; 19(2): 4-12. doi: 10.31631/2073-3046-2020-202-4-12. (In Russ.)

5. Worldometer. Coronavirus pandemic COVID-19. URL: https://www.worldometers.info/coronavirus/\#countries (Accessed 18.08.2020). (In Russ.)

6. Official data on coronavirus in Russia. Up-to-date numbers. URL: https://стопкоронавирус.pф/ (Accessed 18.08.2020). (In Russ.)

7. Bugorkova SA. Some aspects of the formation of the immune response in COVID-19 patients. COVID-19 Preprints [Preprint]. 2020. URL: https://covid19-preprints.microbe.ru/article/21. doi: 10.21055/preprints-3111717. (In Russ.)
8. Garcia LF. Immune response, inflammation, and the clinica spectrum of COVID-19. Front Immunol. 2020; 11: 1441. doi: 10.3389/ fimmu.2020.01441

9. Maggi E, Canonica GW, Moretta L. Covid-19: Unanswered questions on immune response and pathogenesis. J Allergy Clin Immunol. 2020; 146(1): 18-22. doi: 10.1016/j.jaci.2020.05.001

10. Hou $\mathrm{H}$, Wang $T$, Zhang B, Luo $Y$, Mao L, Wang $F$, et al. Detection of $\operatorname{lgM}$ and $\mathrm{IgG}$ antibodies in patients with coronavirus disease 2019. Clin Transl Immunology. 2020; 9(5): e01136. doi: 10.1002/cti2.1136

11. Liu J, Guo J, Xu Q, Cai G, Chen D, Shen Y. Detection of IgG antibody during the follow-up in patients with COVID-19 infection Crit Care. 2020; 24(1): 448. doi: 10.1186/s13054-020-03138-4

\section{Сведения $0 б$ авторах}

Балахонов Сергей Владимирович - доктор медицинских наук, профессор, директор, ФКуз Иркутский научно-исследовательский противочумный институт Сибири и Дальнего Востока Федеральной службы по надзору в сфере защиты прав потребителей и благополучия человека, e-mail: balakhonov.irk@mail.ru, http://orcid.org/0000-0003-4201-5828 Дубровина Валентина Ивановна - доктор биологических наук, заведующая лабораторией патофизиологии, ФКуз Иркутский научно-исследовательский противочумный институт Сибири и Дальнего Востока Федеральной службы по надзору в сфере защиты прав потребителей и благополучия человека, e-mail: dubrovina-valya@mail.ru, http://orcid.org/0000-0001-8561-6207

Чеснокова Маргарита Валентиновна - доктор медицинских наук, заведующая отделом научного и учебно-методического обеспечения, ФКУз Иркутский научно-исследовательский противочумный институт Сибири и Дальнего Востока Федеральной службы по надзору в сфере защиты прав потребителей и благополучия человека, e-mail: adm@chumin.irkutsk.ru, http://orcid.org/0000-0001-5489-9363

Войткова Валентина Владимировна - кандидат биологических наук, старший научный сотрудник лаборатории патофизиологии, Фкуз Иркутский научно-исследовательский противочумный институт Сибири и Дальнего Востока Федеральной службы по надзору в сфере защиты прав потребителей и благополучия человека e-mail:vvoitkova@mail.ru, http://orcid.org/0000-0002-0685-7625

Пятидесятникова Анна Борисовна - младший научный сотрудник лаборатории патофизиологии, ФКуз Иркутский научно-исследовательский противочумный институт Сибири и Дальнего Востока Федеральной службы по надзору в сфере защиты прав потребителей и благополучия человека, e-mail: smy_irkutsk@mail.ru, http://orcid.org/0000-0002-6381-4517

Брюхова Дарья Дмитриевна - младший научный сотрудник лаборатории патофизиологии, ФКУЗ Иркутский научно-исследовательский противочумный институт Сибири и Дальнего Востока Федеральной службыпо надзорув сфере защиты правпотребителей и благополучия человека, e-mail: darabrukhov@mail.ru, https://orcid.org/0000-0002-5589-9522 Киселева Наталья Олеговна - лаборант-исследователь лаборатории патофизиологии, ФКУЗИркутский научно-исследовательский противочумный институтСибири и Дальнего Востока Федеральной службы по надзору в сфере защиты прав потребителей и благополучия человека, e-mail: smy_irkutsk@mail.ru, https://orcid.org/0000-0001-6678-2998 Корытов Константин Михайлович - научный сотрудниклаборатории патофизиологии, ФКУз Иркутский научно-исследовательский противочумный институт Сибири и Дальнего Востока Федеральной службы по надзору в сфере защиты прав потребителей и благополучия человека, e-mail: konstmikhkor@yandex.ru, http://orcid.org/0000-0003-1137-6049 Кузнецова Тамара Григорьевна-заместитель главного врача по организационно-методической работе, ОГБУз «Районнаябольница г. Бодайбо», e-mail:adm@chumin.irkutsk.ru Маркевич Жанна Викторовна - заместитель главного врача по лечебной работе, ОГБУз «Районная больница г. Бодайбо», e-mail: adm@chumin.irkutsk.ru

\section{Information about the authors}

Sergey V. Balakhonov - Dr. Sc. (Med.), Professor, Director, Irkutsk Antiplague Research Institute of Siberia and Far East of Rospotrebnadzor, e-mail: adm@chumin.irkutsk.ru, https://orcid.org/0000-0003-4201-5828

Valentina I. Dubrovina - Dr. Sc. (Biol.), Head of the Laboratory of Pathophysiology, Irkutsk Antiplague Research Institute of Siberia and Far East of Rospotrebnadzor, e-mail: dubrovinavalya@mail.ru, https://orcid.org/0000-0001-8561-6207

Margarita V. Chesnokova - Dr. Sc. (Med.), Professor, Head of the Department of Scientific and Academic Support, Irkutsk Antiplague Research Institute of Siberia and Far East of Rospotrebnadzor, e-mail: adm@chumin.irkutsk.ru, https://orcid.org/0000-0001-5489-9363

Valrntina V. Voitkova - Cand. Sc. (Biol.), Senior Research Officer at the Laboratory of Pathophysiology, Irkutsk Antiplague Research Institute of Siberia and Far East of Rospotrebnadzor, e-mail: vvoitkova@mail.ru, http://orcid.org/0000-0002-0685-7625

Anna B. Pyatidesyatnikova - Junior Research Officer at the Laboratory of Pathophysiology, Irkutsk Antiplague Research Institute of Siberia and Far East of Rospotrebnadzor, e-mail: smy_irkutsk@mail.ru, http://orcid.org/0000-0002-6381-4517

Daria D. Bryukhova - Junior Research Officer at the Laboratory of Pathophysiology, Irkutsk Antiplague Research Institute of Siberia and Far East of Rospotrebnadzor, e-mail: darabrukhov@ mail.ru, https://orcid.org/0000-0002-5589-9522

Natalya 0. Kiseleva - Clinical Research Assistant at the Laboratory of Pathophysiology, Irkutsk Antiplague Research Institute of Siberia and Far East of Rospotrebnadzor, e-mail: smy_irkutsk@mail.ru, https://orcid.org/0000-0001-6678-2998

Konstantin M. Korytov - Research Officer at the Laboratory of Pathophysiology, Irkutsk Antiplague Research Institute of Rospotrebnadzor, e-mail: konstmikhkor@yandex.ru, http://orcid.org/0000-0003-1137-6049

Tamara G. Kuznetsova - Deputy Chief Physician for Organization and Methodology, Bodaybo District Hospital, e-mail: adm@chumin.irkutsk.ru

Zhanna V. Markevich - Deputy Chief Physician for Medical Work, Bodaybo District Hospital, e-mail: adm@chumin.irkutsk.ru

\section{Вклад авторов}

Балахонов С.В. - планирование научной темы, оформление статьи.

Дубровина В.И. - планирование эксперимента, анализ результатов, написание статьи

Чеснокова М.В. - подбор индикаторной группы, подготовка эксперимента, написание статьи.

Войткова В.В. - планирование эксперимента, анализ результатов, оформление статьи.

Пятидесятникова А.Б. - постановка реакций, учёт и анализ результатов.

Брюхова Д.Д. - постановка реакций, учёт и анализ результатов.

Киселева Н.0. - постановка реакций, учёт результатов.

Корытов К.М. - планирование эксперимента, постановка реакций, учёт и анализ результатов, написание статьи.

Кузнецова Т.Г. - работа с пациентами по подбору добровольцев, обеспечение забора материала для исследования.

Маркевич Ж.В. - обеспечение забора материала для исследований. 